DOI 10.18551/rjoas.2021-04.15

\title{
ROLES OF LNCRNAS IN MAIZE
}

\author{
Neupane P.*, Bhattarai K., Maharjan B., Acharya S., Bigyan K.C., \\ Pandit R., Regmi R., Bhusal B.
}

Department of Plant Breeding, PG Program, Institute of Agriculture and Animal Science, Tribhuvan University, Kritipur, Nepal

\author{
Dr. Poudel Mukti Ram \\ Institute of Agriculture and Animal Science, Rupandehi, Nepal \\ *E-mail: pritikaneupane58@gmail.com \\ ORCID: 0000-0003-0038-2240
}

\begin{abstract}
Long non-coding RNAs (IncRNAs) are non-coding RNAs not coding for protein which are usually $>200$ nucleotides in length and have various biological functions. Most recent advancements about role of IncRNAs in maize is compiled in this article. In maize IncRNAs function as abiotic stress tolerance including drought, boron, salt, help in growth regulation by influencing flowering time, help in seed development and play role in low phosphate tolerance, they are also responsive to mycorrhizal fungi. This review is intended to have overall view on maize IncRNAs and guide in further research on maize IncRNAs so that IncRNAs can be used in maize improvement.
\end{abstract}

\section{KEY WORDS}

Non-coding RNA, sequencing, stress tolerance, molecular genetics, genetic manipulation.

Development of sequencing technology and transcriptome analysis has given new prospective to the how non coding RNAs (ncRNAs) function (Nejat and Mantri, 2017) and has given newer prospective to central dogma. IncRNAs are among $98-99 \%$ of transcribed RNA that do not code protein ( Fang et.al, 2018) which were considered as transcriptional noise for long time( Fok et. al,2017) and contain no more than one short( $<100$ amino acids) open reading frames. Open reading frames are part of reading frames that can be translated.

IncRNAs scans can be done by cDNA/ETS in silico mining, whole genome tilling array, RNA-seq approaches and epigenetic signature-based methods. Many similarities between IncRNAs and mRNAs (Derrien et.al, 2012; Goss et al, 2016) and their roles in regulation of complex mechanism has encouraged scientist to study more on IncRNAs. IncRNAs are expressed in tissue/ developmental stage specific manner, up and down regulated by transcription factor. A large proportion of IncRNAs are either derived from transposable elements or contain remnants of TEs.

IncRNAs are involved in transcriptional and post-transcriptional regulation through complex mechanism regulation and has come in highlight in recent years though study about plant IncRNAs are quite limited. In Arabidopsis thaliana, LncRNAs like COOLAIR and COLDAIR help in flowering time (Swiezewskiet al., 2009; Hoe et al., 2011) HID1 in photo morphogenesis (Wang et al., 2014), IPS1 in phosphate homeostasis (Franco et al., 2013), asHSFB2a play role in vegetative and gametophytic development (Wunderlich et al., 2014), APOLO in Auxin controlled development (Ariel et al., 2014), ASCO-IncRNAs in lateral root development (Bardou et al., 2014). In rice IncRNAs such as OSPI1 in phosphate homeostasis (Wasaki et al., 2003). Similarly in Barley HvCes $A_{6}$ Inc-NAT in cell wall synthesis (Held et al., 2008). In soya bean, GmeNOD40 in nodule formation (Yang et al., 1993) but study about IncRNAs in maize, their regulation, roles are long way to go. This review article summarize emerging functions of IncRNAs in maize as abiotic stress tolerance including drought, boron, salt, low Phosphorous tolerance, its role in growth regulation, response to mycorrhizal fungi. 
Table 1 - IncRNAs in abiotic Stress tolerance

\begin{tabular}{|c|c|c|c|c|}
\hline IncRNAs & Functions & Mechanism & Reference & Remarks \\
\hline PILNCR1 & $\begin{array}{l}\text { low } \\
\text { phosphate } \\
\text { tolerance }\end{array}$ & $\begin{array}{l}\text { IncRNAs by } \\
\text { interacting with } \\
\text { miRNA as } \\
\text { PILNCR1-miR }{ }_{399} \\
\text { regulatory } \\
\text { module }\end{array}$ & $\begin{array}{l}\text { (Du et al., } \\
2018)\end{array}$ & $\begin{array}{l}\text { PILNCR1 stands for Pi-deficiency-induced long } \\
\text { non-coding RNA } 1 .\end{array}$ \\
\hline $\begin{array}{l}664 \\
\text { IncRNAs }\end{array}$ & $\begin{array}{l}\text { drought } \\
\text { responsive in } \\
\text { maize } \\
\text { seedlings } \\
\text { drought } \\
\text { resistance }\end{array}$ & & $\begin{array}{l}\text { (Lv et al., } \\
2016) \\
\\
\text { (Zhang et } \\
\text { al.,2014) }\end{array}$ & $\begin{array}{l}\text { TCONS_00082174 and TCONS_00000649 show } \\
\text { leaf specific expression in drought. } \\
\text { TCONS_00037470 and TCONS } 00012768 \text { are } \\
\text { down regulated in drought stressed root. } \\
\text { GMRZM2G088590-TO4 shows temporal specific } \\
\text { expression. } \\
\text { GRMZM2G574383_TO1exhibits roots specific } \\
\text { expression. (Zhang et al.,2014) } \\
\text { In comparison to protein coding genes drought } \\
\text { responsive IncRNAs show higher tissue and } \\
\text { development specificity.Reproductive stage is the } \\
\text { most sensitive growth stage in drought.(Pang et } \\
\text { al., 2019) }\end{array}$ \\
\hline $\begin{array}{l}637 \\
\text { IncRNAs }\end{array}$ & $\begin{array}{l}\text { nitrogen } \\
\text { responsive }\end{array}$ & & $\begin{array}{l}\text { (Lv et al., } \\
2016)\end{array}$ & $\begin{array}{l}\text { Nitrogen responsive IncRNAs are enrich in three } \\
\text { co-expressed modules. Gene in enriched } \\
\text { modules are mainly involved in NADH } \\
\text { dehydrogenase activity, oxidative phosphorylation } \\
\text { and nitrogen compounds metabolic process. }\end{array}$ \\
\hline $\begin{array}{l}1710 \\
\text { IncRNAs }\end{array}$ & $\begin{array}{l}\text { responsive to } \\
\text { salt and } \\
\text { boron stress }\end{array}$ & & $\begin{array}{l}\text { (Huanca- } \\
\text { Mamani et } \\
\text { al., 2018) }\end{array}$ & - \\
\hline
\end{tabular}

Table 2 - IncRNAs function in growth and development

\begin{tabular}{|c|c|c|c|c|}
\hline IncRNAs & Functions & Mechanism & Reference & Remarks \\
\hline HC-IncRNAs & $\begin{array}{l}\text { paramutation in } \\
\text { maize }\end{array}$ & & $\begin{array}{l}\text { (Lin et al., } \\
2014)\end{array}$ & $\begin{array}{l}\text { Interaction between alleles that } \\
\text { leads to mitotically and meiotically } \\
\text { heritable change in gene } \\
\text { expression is termed as } \\
\text { paramutation }\end{array}$ \\
\hline 63 IncRNAs & $\begin{array}{l}\text { Arbuscular } \\
\text { Mycorrhizal (AM) } \\
\text { fungi-responsive } \\
\text { IncRNAs }\end{array}$ & & $\begin{array}{l}\text { (Han et } \\
\text { al.,2019) }\end{array}$ & $\begin{array}{l}\text { differentially expressed in fungal } \\
\text { colonized root }\end{array}$ \\
\hline GRMZm2G700665 & $\begin{array}{l}\text { influence flowering } \\
\text { time in maize }\end{array}$ & & $\begin{array}{l}\text { (Salvi et } \\
\text { al., 2007) }\end{array}$ & $\begin{array}{l}\text { GRMZm2G700665 is located } 70 \\
\text { kb upstream of ZmRap2 gene }\end{array}$ \\
\hline TCONS-00089485 & $\begin{array}{l}\text { may play role in } \\
\text { embryo seed and } \\
\text { ovule tissue }\end{array}$ & & $\begin{array}{l}\text { (Lin et al., } \\
2014)\end{array}$ & $\begin{array}{l}\text { TCONS- } 00089485 \text { expressed in } \\
\text { Vgt1 regulatory region (vegetative } \\
\text { to generative transition } 1 \text { ) }\end{array}$ \\
\hline 7 novel IncRNAs & $\begin{array}{l}\text { general } \\
\text { development and } \\
\text { metabolic } \\
\text { processes in maize } \\
\text { seed }\end{array}$ & $\begin{array}{l}\text { as potential } \\
\text { competing } \\
\text { endogenous } \\
\text { RNA (ceRNA) }\end{array}$ & $\begin{array}{l}\text { (Zhu et al., } \\
\text { 2017). }\end{array}$ & - \\
\hline
\end{tabular}

The inheritance of IncRNAs expression patterns shows apparent transgressive segregation. Maize IncRNAs are less affected by cis than by trans genetic factors. High confidence IncRNA having average length of $463 \mathrm{bp}$ and coding for fewer exons than annotated genes are mostly expressed in tissue specific manner which is even supported by epigenetic marks (Lin et al., 2014).

Maize transposable elements contribute to long non-coding RNA that is regulatory hubs for abiotic stress response (Ly et al., 2019) in maize. Recent findings on IncRNAs functioning as abiotic stress tolerance are shown in the Table 1.

In silico bioinformatics pipeline used in maize on limited set of full-length cDNA sequence showed 1802 IncRNAs of which nearly $60 \%$ were precursors of small RNAs. Small 
RNAs are non-coding RNA which helps to inhibit or increase expression of target genes (p2) and many other biological functions.

Conclusion. Though few studies have been done to study IncRNAs in maize there is still a lot to be done to explore other IncRNAs and their role in accurate detail and conformation by molecular and genetic approaches is yet to be done and their regulation in maize so as to use such IncRNAs in crop improvement programs such as stress tolerant varieties.

\section{REFERENCES}

1. Nejat, N., \& Mantri, N. (2017). Emerging roles of long non-coding RNAs in plant response to biotic and abiotic stresses. Critical Review in Biotechnology, 38(1), 93-105. doi: 10.1080/073888551.2017.1312270.

2. Fang, S.S., Zhang, L.L., Guo, J.C., Niu, Y.W., Wu, Y., Li, H., Zhao, L.H., Li, X.Y, Teng, X.Y, Sun, X.H., Sun, L., Zhang, M.Q., Chen, R.S., \&Zhao, Y.(2018).NONCODEV5: A comprehensive annotation database for long noncoding RNAs. Nucleic Acids Research, 1(46), 308-314. doi:10.1093/nar/gkx1107.

3. Fok, E.T., Scholefield, J., Fanucchi, S., \& Mhlanga, M.M. (2017).The emerging molecular biology toolbox for the study of long non coding RNA biology. Epigenomics, 9(10), 13171327. doi: 10.2217/epi-2017-0062.

4. Mattick, J.S., \& Rinn, J.L. (2015) Discovery and annotation of long non-coding RNAs. Nature Structural and Molecular Biology, 22(1), 5-7. doi: 10.1038/nsmb.2942.

5. Wang, K.C., \& Chang, H.Y. (2011). Molecular mechanism of long non-coding RNAs. Molecular Cell, 43(6), 904-914. doi: 10.1016/j.molcel.2011.08.018.

6. Swiezewski, S., Liu, F.,Magusin, A., \& Dean, C.(2009) Cold-induced silencing by long antisense transcripts of Arabidopsis Polycomb target. Nature, 462(7274), 799-802. doi: 10.1038 /nature08618.

7. Heo, J.B., \&Sung, S. (2011). Vernalization-mediated epigenetic silencing by a long intronic noncoding RNA. Science, 331(6013), 76-79. doi: 10.1126/science.1197349.

8. Wang, Y., Fan, X., Lin, F., He, G., terzaghi, W., Zhu, D., \& Deng, X.W. (2014). Arabidopsis noncoding RNA mediates control of photomorphogenesis by red light. PNAS, 111(28), 10359- 10364. doi: 10.1073/pnas.1409457111.

9. Franco, J.M., Secco, D., lecampion, C., Robaglia, C., Shu, Q.Y., \& Poirier, Y. (2013). A rice cis-natural anti sense RNA acts as translational enhancer for its cognate mRNA and contributes to phosphate homeostasis and plant fitness. Plant Cell, 25(10), 4166-4182. doi: $10.1105 /$ tpc. 113.116251 .

10. Wunderlich, M., Gross-Hardt, R., \& Schoffl, F. (2014). Heat shock factor HSFB2a involved in gametophyte development of Arabidopsis thaliana and its expression is controlled by a heat-inducible long non-coding antisense RNA. Plant Molecular Biology, 85(6), 541-550. doi: 10.1007/s11103-014-0202-0.

11. Ariel, F., Jegu, T., Latrasse, D., Romero-Barrios, N., Christ, A., Benhamed, M., Crespi, M. (2014).Non coding transcription by alternate RNA polymerase dynamically regulates an auxin-driven chromatin loop. Molecular Cell, 55(3), 383-396. doi: 10.1016/J.MPLCEL.2014.06.011.

12. Bardou, F., Ariel, F., Simpson, C.G., Romero-Barrios, N., Laporte, P., Balzergue, S., Brown, J.W.S.,\& Crespi, M. (2014). Long noncoding RNA modulates alternative splicing regulators in Arabidopsis. Developmental Cell, 30(2), 166-176. doi: 10.1016/j.devcel.2014.06.017.

13. Wasaki, J., Yonetani, R., Shinano, T., Kai, M., \& Osaki, M. (2003) Expression of the $\mathrm{OsPl}_{1}$ gene, cloned from rice roots using cDNA microarray, rapidly responds to phosphorous status. New Phytologist Foundation, 158(2), 239-248. doi: 10.1046/j.14698137.2003.00748.x.

14. Held, M.A., Penning, B., Brandt, A.S., Kessans, S.A., Yong, W., Scofield, S.R., \& Carpita, N.C. (2008). Small interfering RNAs from natural antisense transcripts derived from a 
cellulose synthase gene modulate cell wall biosynthesis in barley. PNAS, 105(51), 20534-20539. doi: 10.1073/pnas.0809408105.

15. Yang, W.C., Katinakis, P., Hendriks, P., Smolders, A., Vries, F.de., Spee, J., Kammen,A.van., Bisseling, T., Franssen, H.(1993). Characterization of GmENOD40, a gene showing novel patterns of cell-specific expression during soyabean nodule development. Plant Journal, 3(4), 573-585. doi: 10.1046/j.1365-313x.1993.03040573.x.

16. Lin, L., Eichten, S.R., Shimizu, R., Petsch, K., Yeh, C-T., Wu, Wei., Chettoor, A.M., Cole, R.A., Fowler, J.E., Evans, M. M. S., Scanlon, M.J., Yu, J., Schnable, P.S., Timmermans, M.C.P., Springer, N.M., \& Muehlbauer, G.J. (2014). Genome-wide discovery and characterization of maize long non-coding RNAs. Genome Biology, 15(40). doi: 10.1186/gb-2014-15-2-r40.

17. Lv, Y., Hu, F., Zhou, Y., Wu, Feilong., \& Gaut, B.S. (2019).Maize transposable elements contribute to long non-coding RNAs that are regulatory hubs for abiotic stress response. BMC Genomics, 20(864). doi: 10.118/s12864-019-625-5.

18. Du, Q., Wang, K., Zou, C., Xu, C., \& Li, W-X. (2018). The PILNCR1-miR ${ }_{399}$ Regulatory model is important for low phosphate tolerance in maize. Plant Physiology, 177(4), 34. doi: 10.1104/pp.18.00034.

19. Ly, Y., Liang, Z., Ge, M., Qi, W., Zhang, T., Lin, F., Peng, Z., \& Zhao, H. (2016). Genomic-wide identification and functional prediction of nitrogen-responsive intergenic and intronic long non- coding RNAs in maize (Zea mays L.). BMC Genomics, 17(350), doi: 10.1186/s12864-016-2650-1.

20. Zhang, W., Han, Z., Guo, Q., Liu, Y., Zheng, Y., Wu, F. et al. (2014). Identification of maize long non-coding RNAs responsive to drought stress. PLOS ONE, 9(6), e9895 doi: 10.1371/journal.pone.0098958.

21. Pang, J., Zhang, Xia., Ma, X., \& Zhao, J.(2019). Spatio-Temporal Transcriptional Dynamics of maize long non-coding RNAs responsive to drought stress. Genes (Basel), 10(2), 138. doi: 10.3390/genes10020138.

22. Huanca-Mamani, W., Arias-Carraso, R., Cardenas-Ninasivincha, S., Rojas-Herrera, M., Sepulveda-Hermosilla, G., Caris-Maldonado, J.C., Batias, E., \&Maracaja-Coutinho, V. (2018).Long non-coding RNAs responsive to salt and boron stress in hyper-arid Lluteno maize from Atacama Desert. Genes (Basel, 9(3), 170. doi: 10.3390/genes9030170.

23. Han, G., Cheng, C., Zheng, Y., Wang, X., Xu, Y., Wang, W., Zhu, S., \& Cheng, B. (2019).Identification of long non-coding RNAs and the regulatory Network to Arbuscular Mycorrhizal Fungi Colonization in Maize roots. International Journal of Molecular Science, 20(18), 4491. doi: 10.3390/ijms20184491.

24. Salvi, S., Sponza, G., Morgante, M., Tomes, D., Niu, X., Fengler, K.A., Meeley R., Ananiev, E.V., Svitashev, S., Bruggemann, E, Li, B., Hainey, C.F., Radovic, S., Zaina, G., Rafalski,J.-A., Tingey,S.V., Miao, G-H., Phillips, R.L.,\& Tuberosa, R. (2007). Conserved non-coding genomic sequence associated with a flowering time quantitative trait locus in maize. PNAS, 104(27), 11376-11381. doi: 10.1073/pnas.0704145104.

25. Zhu, M., Zhang, M., Xing, L., Li, W., Jiang, H., Wang, L., \& Xu, M. (2017). Transcriptomic Analysis of Long non-coding RNAs and Coding genes uncovers a complex regulatory network that is involved in maize seed development. BMC Genomics, 8(10). doi: 10.1186/s12864-016-2650-1. 